Marianna Chłopek-Labo

\title{
Literatura jako projekt, czyli zamysł literacki autora Na przykładzie utworów Borisa Akunina
}

Obecnie obserwujemy zacieranie się granic na wielu płaszczyznach: społecznej, politycznej oraz kulturowej. Hybrydyzacja kultury jest zjawiskiem globalnym, szczególnie zaś dotyczy różnych literatur.

Przeprowadzenie podziału między literaturą wysoką a masową czytelnika stwarza wiele problemów. Brakuje jednolitej klasyfikacji tego, co należy do kanonu lub na jakiej podstawie klasyfikować pisarzy jako autorów literatury pięknej, masowej czy popularnej. Owo zacieranie się granic otwiera pole do zaistnienia zjawisk, istniejących na styku w - jak określał Hegel - polu pomiędzy.

Właśnie tutaj znajdują się pisarze tacy jak m.in. Haruki Murakami, Wiktor Pielewin, Boris Akunin. Ten ostatni, prowadzi grę z tradycją literacką, czyni ją inspiracją i jednocześnie narzędziem do tworzenia projektów literackich. Celem referatu jest prześledzenie w jaki sposób i z jakim efektem są przekraczane granice norm literackich w utworach Akunina. Poszukamy też odpowiedzi na pytanie o możliwe skutki potraktowania literatury, czyli dziedzictwa kulturowego, czyli kanonu literackiego jako produkt podlegający dowolnym modyfikacjom.

\section{Relacja między kulturą wysoką i kulturą popularną}

Znany nam istniejący przez wieki podział na kulturę wysoką i kulturę niską zanika wraz z postępującym cywilizacyjnym. Jak zaobserwował Lichański odejście od wyznaczanego przez tradycyjną filologię kanonu literackiego opartego na literaturze klasycznej 
spowodowało zanikanie świata wspólnych odwołań obrazów literackich [Lichański 2005: 33].

Przez długi czas obserwowano zależność między rodzajem czytelnika, a jego wyborami literackimi. Inteligencja była kształtowana przez kanon literacki, natomiast czytelnik masowy najczęściej sięgał po literaturę masową, która najczęściej nie reprezentowała wartości leżących u podstaw kultury [Ortega 1982: 103].

Przemianom kulturowym XX wieku nieuchronnie towarzyszy dyskusja o relacjach między kulturą wysoką a popularną.

Powstanie i rozwój kultury masowej w dużej mierze przyczyniły się [...] do zmiany oblicza współczesnej sztuki, z jednej strony, poprzez zawarte w samej kulturze masowej dążenie do homogenizacji z kulturą wysoką, z drugiej zaś, ze względu na jawne czerpanie kultury wysokiej ze źródeł kultury masowej [Feartherstone 1996: 302].

Wraz z pojawieniem się kulturowej różnorodności, w świecie literatury i sztuki zaistniała tendencja „zapożyczania” chwytów z arsenału literatury klasycznej. Wynika z tego, że kultura popularna jako medium, z którym obcujemy się na co dzień i przez które dokonujemy filtracji rzeczywistości, stała się narzędziem w ręku pisarzy. Z tego powodu przypisanie utworu do repertuaru literatury wysokiej lub popularnej zdaje się zależeć od subiektywnej oceny utworu przez odbiorcę. Ocena ta jest formowana na podstawie walorów estetycznych i poznawczych tekstu [Puzynina 2005: 17].

Kultura popularna przez niektórych badaczy, pisarzy i literaturoznawców bywa traktowana jak zagrożenie, przez innych jak lustrzane odbicie swoich czasów.

\section{Grigorij Czchartiszwili i jego poglądy na konwencję literacką}

Niemal w każdej literaturze narodowej są pisarze, którzy uczynili z kultury popularnej narzędzie zabawy i swoistej gry z czytelnikiem. W rosyjskiej literaturze jednym $\mathrm{z}$ takich autorów jest filolog, tłumacz, 
eseista Grigorij Czchartiszwili, znany pod pseudonimem Boris Akunin. Grigorij Czchartiszwili debiutował w 1998 roku i prawie natychmiast jego utwory zostały okrzyknięte prawdziwą rewolucją gatunkową $\mathrm{w}$ rosyjskiej prozie [Domogalla 2008: 76] oraz przetłumaczone na wiele języków, w tym na polski.

Debiut pod pseudonimem i przez dwa lata ukrywanie swoich prawdziwych danych pozwoliło Czchartiszwilemu stworzyć wokół siebie aurę tajemniczości i zainteresowania. To działanie zostało poparte strategią wydawcy, który prezentował czytelnikom kolejne książki jako typowy produkt komercyjny. Czytelnika rzeczywistego coraz bardziej interesowała zawiła intryga kryminału i atmosfera tworząca się wokól autora [Komarowa 2001: 72]. Poprzez odwołania do rosyjskiej historii, mentalności i kultury kryminały Akunina były postrzegane przez czytelników jako wyzwanie intelektualnym. Już te czynniki mogły przesądzić o sukcesie pisarza. Jednak strategia marketingowa Akunina nie kończyła się na tym. Czchartiszwili potraktował literaturę jako projekt, czyli niepowtarzalne i złożone działanie, rezultatem którego jest realizacja z góry założonego celu [Trocki, Grusza, Ogonek 2003: 25]. W jednym z wywiadów Czchartiszwili zaprezentował swoje uzasadnienie takiego postępowania:

Wymyśliłem wielokomponentowy, skomplikowany szkic. Wydaje mi się, że projekt. (...) Czym różni się literatura od literatury-projektu? Moim zdaniem tym, że korzenie literatury są w sercu, a projektu - w głowie $^{1}$ [przekł. M.Ch.-L.].

W następnym podrozdziałach zostaną scharakteryzowane wybrane projekty literackie G. Czchartiszwili.

1 «Я придумал многокомпонентный, замысловатый чертеж. Поэтому - проект. <...> Чем, собственно, Аитературы отличается от митературного проекта? По-моему, тем, что корни митературы - в серАце, а корни митературного проекта - в голове» [Komarowa 2001: 4]. 


\section{Projekt Przygody Erasta Fandorina}

Pierwszym projektem Akunina był cykl 15 retrokryminałów Przygody Erasta Fandorina. Autor tego cyklu powieści świadomie prowadzi wielopoziomową grę z potencjalnym czytelnikiem tekstu [Timina, Markowa, Kiaszto 2011: 240]. Wyróżniono pięć poziomów gry: gatunkowy, bohatera, fabuły, realiów kulturowych, językowy. Spróbujmy przyjrzeć się tym poziomom.

Poziom gatunków jest realizowany poprzez zaprezentowanie przez Czchartiszwilego w jednym cyklu wszystkich gatunków klasycznego kryminału: debiutancki Azazel (Азазель 1998, wyd. polskie 2003) to kryminał konspiracyjny, kolejna powieść Gambit turecki (Турецкий гамбит 1998, wyd. polskie 2003) to kryminał szpiegowski, trzecia z kolei powieść Lewiatan ( Аевиафан 1998, wyd. polskie 2003) - hermeneutyczny, polityczny kryminał reprezentują powieści Śmierć Achillesa (Cмерmь Axuлнeca 1998, wyd. polskie 2003) oraz Radca stanu (Статский советник 1999, wyd. polskie 2004), powieść łotrzykowska Walet pikowy (Пиковый валет 1998, wyd. polskie 2003) i powieść o seryjnym zabójcy Dekorator (Aeкорamop 1998,wyd. polskie 2003) następnie Akunin przygotował kryminał obywatelski (Koronacja - Коронация, или Последний из романов 2000, wyd. polskie 2004), dekadencki (Kochanka śmierci - Аюбовница смерти 2001, wyd. polskie 2004), dickensowski (Kochanek śmierci - Аюбовник смерти 2001, wyd. polskie 2004), egzotyczny (Diamentowa karoca ${ }^{3}$ - Аммазнал колесница 2003, wyd. polskie 2005), remake klasycznych kryminałów (Nefrytowy różaniec ${ }^{4}$ - Heфpumoвые

2 Za tę powieść Akunin otrzymał prestiżową nagrodę Antybooker.

3 Popularność egzotycznej powieści Diamentowa karoca przypadła na moment zainteresowania kulturą japońską.

${ }^{4}$ Można zauważyć, że autor sięga po bogaty repertuar gatunkowy powieści kryminalnych. Odwołuje się tym samym do tradycji ustanowionej przez takich mistrzów kryminału jak Artur Conan Doyle, Edgard Poe, Agatha Christie i in. Tego typu nawiązania zostały podsumowane w następująco: „Literatura popularna specjalnie się nie zmienia, ponieważ nie zmieniają się oczekiwania jej czytelników” za: Gemra [2005: 100]. 
чёmкu 2007, wyd. polskie 2009), kryminał teatralny Świat jest teatrem (Bесь мир meamp 2009, wyd. polskie 2012) i Czarne miasto (Черный гоpod 2012, brak wydania polskiego).

Wymienione kryminały tworzą serię, którą łączy osoba głównego bohatera ${ }^{5}$ - detektywa Erasta Fandorina. Erast ma cechy bohatera literatury pięknej - to intelektualista, osoba wykształcona i wychowana zgodnie z pewnym etosem. Bohater z założenia nie jest typowym Rosjaninem, posiada $\mathrm{w}$ sobie cechy rosyjskiego inteligenta, japońskiego samuraja oraz angielskiego dżentelmena. Fandorin kontynuuje tradycję wielkich detektywów jednocześnie zapożyczając najbardziej wyróżniające cechy każdego z nich - szarmancki, z rozwiniętymi zdolnościami analitycznymi, cieszący się powodzeniem u kobiet, nieco ekscentryczny, jednak nie na tyle by być traktowanym jak ktoś z zewnątrz. Erast Fandorin wzbudza sympatię czytelnika. W ten sposób prezentowany jest poziom bohatera.

Trzeci poziom tworzy fabuła. Akunin nawiązuje do tradycji klasyków gatunku - Artura Conan Doyla, Agaty Christi, Edgara Alana Poe, czego przykładem jest chociażby remake Nefrytowy różaniec. Jednak na tym pisarz nie poprzestaje, bo wykorzystując charakterystyczne elementy gatunku, takie jak wartka akcja, morderstwa i porwania, piękne kobiety, Akunin dodaje nowe, charakterystyczne tylko dla jego utworów [Domogalla 2008: 77].

Poprzez przedstawienie historii Rosji XIX i początku XX w. przejawia się nawiązanie do obrazu mitycznej Rosji. Świat przedstawiony powieściach popularnych często jest krainą marzeń, umożliwiającą ucieczkę od szarej codzienności [Legutko 2005: 111]. Wrażenie niezwykłości jest dodatkowo potęgowane przez zaznaczanie egzotyki przedstawianej rzeczywistości jak również poprzez podkreślanie jej

${ }^{5}$ W kulturze masowej często obserwowana jest seryjność, czyli skupienie fabuł kolejnych utworów wokół głównego bohatera. Ten bohater jako konstrukt jest powołany by dokonywać rzeczy niezwykłych, ryzykować i wygrywać (utwory literatury popularnej zawsze kończą się happy endem). Detektyw reprezentuje członka społeczeństwa, który walczący ze złem pochodzącym z zewnątrz (przestępcy) lub z wewnątrz (szpiedzy). 
dawności. Jednakże jak pisze Ranczin [2004: 396], fabuła powieści nie wpisuje się w rosyjski mit o tamtej epoce, natomiast odpowiada zmitologizowanemu wyobrażeniu o aktualnej rzeczywistości.

Czwarty poziom jest osadzony w kulturowych i historycznych realiach Często spotykanym w tekście zjawiskiem literackim jest intertekstualność, która wymaga od odbiorcy wpisanego w tekst znajomości klasyków literatury rosyjskiej i światowej. Można to zaobserwować na przykładzie powieści F.M. Już w tytule kryminału rosyjski czytelnik może rozpoznać inicjały wybitnego Fiodora Michajłowicza Dostojewskiego, co więcej fabula utworu dotyczy rękopisu Zbrodni i kary. Aluzje literackie odnajdujemy też w innych utworach.

I ostatni piąty poziom to poziom języka - osadzone w epoce XIX-wiecznej Rosji utwory wymagają od czytelnika chociaż szczątkowej znajomości języka tamtych czasów.

Po sukcesie serii z Erastem Fandorinem, Akunin rozpoczął nową serię skupioną wokół przygód głównego bohatera pt. Prowincjonalny kryminat czyli przygody siostry Pelagii (Приключения Пелагии). Ten cykl składał się z 3 utworów: Pelagia i biały buldog (Пелагия и бельй бульдог 2000, wyd. polskie Oficyna Literacka Noir sur Blanc 2004), Pelagia i czarny mnich (Пелагия и чёрный монах 2001, wyd. polskie Oficyna Literacka Noir sur Blanc 2004), Pelagia i czerwony kogut (Пелаzus и красный петух 2003, wyd. polskie Oficyna Literacka Noir sur Blanc 2004). W międzyczasie autor zaczął publikować utwory z nowej serii Przygody magistra (Приключения магистра): Skrzynia na złoto (А^тын-толобас 2000, wyd. polskie Świat Książki 2005), Lektura nadobowiazkowa (Внеклассное чтение 2002, wyd. polskie Świat Książki 2005), F.M. (Ф.M. 2006, wyd. polskie Świat Książki 2008), Sokót

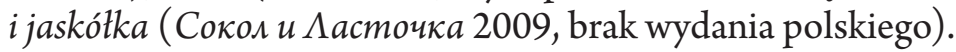

\section{Projekt gatunki}

Równolegle w 2005 roku Czchartiszwili rozpoczął eksperyment z gatunkami powieści, czego wynikiem była seria Gatunki. W literaturze masowej istnieją kanony gatunkowe i tematyczne, funkcjonujące jako modele fabularne utworów stworzonych zgodnie z określonym 
schematem i posiadających wspólną tematykę, włącznie z zestawem typologicznym bohaterów. Kanoniczny początek, estetyczne szablony konstrukcji są wspólne dla wszystkich rodzajów literatury masowej (kryminał, thriller, fantasy, i in.) i to właśnie one tworzą pewne „gatunkowe oczekiwanie” czytelnika i „seryjność” projektów wydawniczych [Czerniak 2008: 207].

Natomiast ten projekt jest prześmiewaniem się ze sztywnych form i uwięzienia utworów w określonej stylistyce i być może jego celem jest pokazanie, że utrzymanie powieści w określonym gatunku nie wymaga od jej autora specjalnego zaangażowania.

Do tej pory w ramach serii ukazały się 4 utwory: Książka dla dzieci (Аетскал книга 2005, wyd. polskie Świat Książki 2007), Powieść szpiegowska (Шиионский роман 2005, wyd. polskie Świat Książki 2006), Fantastyka (Фантастuкa 2005, wyd. polskie Świat Książki 2007), Powieść historyczna (Квест 2008, br. wydania polskiego).

\section{Gry z czytelnikiem}

Książki Akunina są wydawane w kilkuset tysięcznych nakładach, a po wyczerpaniu nakładu wznawiane przez wydawnictwo po raz kolejny. Kim są czytelnicy utworów Akunina?

Książki Akunina adresowane są do czytelnika masowego przynależącego do różnych grup wiekowych. Pisarz podejmuje wyrafinowaną grę z czytelnikiem, proponując mu poszukiwanie w tekście dodatkowych informacji o charakterze kulturowym i historycznym.

Gra podjęta z czytelnikiem wydaje się odpowiadać jego różnorodnym potrzebom. $Z$ jednej strony, utwory spełniają oczekiwania tego masowego odbiorcy, który oczekuje fabuły wartkiej, pełnej przygód i nieoczekiwanych zwrotów akcji. Z drugiej zaś strony, masowy czytelnik odczuwa tęsknotę za wyidealizowanym i szlachetnym bohaterem, którą to tęsknotę zaspokaja czy to Fandorin, czy to siostra Pelagia. Lektura pozwala zaspokoić również tęsknotę za przeszłością, ową utraconą Rosją.

Autor wymaga od odbiorcy wpisanego w tekst, a zatem również od potencjalnego czytelnika przygotowania literackiego, które pomoże 
mu dekodować ukryte w tekście aluzje i odwołania do innych utworów rosyjskiej literatury (Puszkina, Dostojewskiego, Tołstoja, Bułhakowa, Czechowa), klasyki literatury światowej (Szekspira, Eco, Borgesa, Conan-Doyla, Chestertona i in.) i szerokiej wiedzy ogólnej, by odbiorca mógł pewnie poruszać się w Akuninowskim labiryncie licznych cytatów, aluzji, zapożyczonych postaci, przeróbek literatury czy dzieł kultury masowej (kryminały Agaty Christie, filmy o Jamesie Bondzie) [Domogalla 1998: 79].

Możemy zatem stwierdzić, że najprawdopodobniej czytelników książek Akunina możemy zaklasyfikować do trzech różnych grup czytelniczych. Niewątpliwie książki Akunina adresowane są do odbiorcy erudycyjnego, który charakteryzuje się sporym doświadczeniem literackim i zdolnością odczytywania ukrytych w tekście sensów. Drugą grupę czytelników tworzy odbiorca nieerudycyjny i niemasowy, który sięga po tekst literatury masowej, aby zaspokoić pragnienie rozrywki i przyjemności, na co pozwala mu fabuła omawianych powieści. Trzecią grupę stanowi czytelnik masowy z wyniesioną ze szkoły znajomością kanonu literackiego. Tę ostatnią nową grupę tworzą czytelnicy wywodzący się z klasy średniej otwarci na nowy model literatury. Ten nowy model literatury możemy określić jako pomost między literaturą wysoką (artystycznymi środkami wyrazu), a literaturą niską (wybór gatunków niskich).

Utwory Akunina utrzymane są w konwencji gry z kanonem literackim są jednocześnie zorientowane na klasykę oraz nastawione na niszczenie tradycji literackiej czego rezultatem było stworzenie nowych ram gatunkowych powieści kryminalnych, które pozwoliły twórcy otworzyć się na nową kategorię czytelnika. Nie naruszając komfortu intelektualnego swojego czytelnika, Akunin zapewnia swojemu odbiorcy coś, co Barthes nazwał przyjemnością tekstu.

\section{Podsumowanie}

Dotychczas obserwowane binarne opozycje między kulturą wysoką a kulturą popularną zdają się ustępować na rzecz hybrydazacji literatury. Jednym z pionierów tego typu zjawiska na gruncie rosyjskim 
jest pisarz Akunin, którego projekty literackie zostały szeroki rozgłos na europejskim rynku wydawniczym.

Zrealizowany przez Czchartiszwili pomysł na działalność literacką przebiegał według następującego schematu: intryga - odkrycie. Czchartiszwili na początku ukrywał się, później pod pseudonimem Akunin udzielił wywiadu, a następnie przyznał się do napisania utworów z serii Przygody Erasta Fandorina.

Pisarz znalazł niszę na rynku - przepaść między literaturą wysoką, a masową oraz znudzenie czytelników literaturą postmodernistyczną - którą z sukcesem zagospodarował.

Podejmując polemikę z tradycyjnym obrazem literatury, Czchartiszwili jednocześnie poruszył temat roli i statusu twórcy we współczesnym świecie. Opinie badaczy na jego temat są podzielone: jedni uważają, że jego twórczość, wpisując się w nurt postmodernizmu, jest zarazem nowatorskim i pozytywnym powiewem na gruncie rosyjskiej literatury (Ranczin, Cypałkow, Szamanskij). Inni zaś zarzucają tworzenie mu bezwartościowego rus-artu (Nemzer, Nowikow). Te negatywne opinie nie są w stanie zaprzeczyć niewątpliwego sukcesu Akunina i finansowej opłacalności traktowania literatury jako projektu. Natomiast podkreślają one negatywne walory etyczne tego rodzaju podejścia: obniżenie standardów, przeinaczanie historii, tworzenie nowych mitów. Ponadto popularność tego rodzaju literatury ukazuje kondycję czytelnika masowego. Wychodząc poza literaturę rosyjską możemy zaobserwować, że jest to zjawisko globalne, prawdopodobnie podyktowane duchem naszych czasów.

\section{Bibliografia}

Domogalla A. [2008], Rosyjska powieść kryminalna XX-XXI wieku, [w:] Rusycystyczne studia literaturoznawcze, Mazurek H., Kragla J. (red.), Wydawnictwo Uniwersytetu Śląskiego, Katowice.

Featherstone M. [1996], Postmodernizm i estetyzacja życia codziennego, [w:] Postmodernizm. Antologia przekładów, Nycz R. (red.), Wydawnictwo Baran i Suszczyński, Kraków.

Gemra A. [2005], Casus „literatura popularna”: książi dla ludzi, [w:] Relacje między kultura wysoka i popularna w literaturze, języku i edukacji, 
Myrdzik B., Karwatowska M. (red.), Wydawnictwo Uniwersytetu Marii Curie-Skłodowskiej, Lublin, s. 95-103.

Krajewski M. [2003], Kultury kultury popularnej, Wydawnictwo Naukowe UAM, Poznań.

Legutko G. [2005], Powieść popularna czy wysokoartystyczna? O „Marii Magdalenie" Gustawa Danitowskiego, [w:] Relacje między kultura wysoka i popularna w literaturze, języku i edukacji, Karwatowska M., Myrdzik B. (red.), Wydawnictwo Uniwersytetu Marii Curie-Skłodowskiej, Lublin.

Lichański J. [2005], Relacje między kultura wysoka a niska/popularna w literaturze. Glosy do dyskusji wraz z sugestiami metodologicznymi, [w:] Relacje między kultura wysoka a popularna w literaturze, języku i edukacji, Karwatowska M., Myrdzik B. (red.), Wydawnictwo Uniwersytetu Marii Curie-Skłodowskiej, Lublin.

Ortega J. y Gasset. [1982], Bunt mas i inne pisma socjologiczne, Niklewicz P. i Woźniakowski H. (przeł.), PWN, Warszawa.

Puzynina J. [2005], Kultura popularna a kultura wysoka dziś, [w:] Relacje między kultura wysoka i popularna w literaturze, języku i edukacji, Karwatowska M., Myrdzik B. (red.), Wydawnictwo Uniwersytetu Marii Curie-Skłodowskiej, Lublin.

Trocki M., Grucza B., Ogonek K. [2003], Zarzadzanie projektami, Polskie Wydawnictwo Ekonomiczne, Warszawa.

Комарова О. [2001], Новый старый русский. О творчестве Б. Акунина (New Old Russian. About the Writings of B. Akunin) Полярный вестник, Vol. 4.

Ранчин А. [2004], Романы Б.Акунина и класическал традиция, [w: ] Новое sитературное обозрение, $\mathrm{nr} 67$.

Черняк М. [2005], Категория «автора» в массовой митературе. Феномен массовой митературы ХХ века, Изаательство РГПУ им. А.И. Герцена, Санкт-Петрбург.

Современнал русскал митература кониа XX - начала XXI в. [2011], Тимина, Маркова, Кякшто (red.), Издательский центр «Академия», Москва. 